しみである.

演題(2)では，液体陽極を用いることにより陽極の耐久性，X線発生 効率の向上がみられ，プラズマX線の発生が可能でさらには，陽極の 温度を変化させることによりスペクトル分布を調整できる.医療分野 のみならず多方面に応用が期待されるだけに興味ある報告であった。

演題(3)では, 基礎研究用として高出力装置の開発したもので, 小型 軽量にして管電圧 $100 \mathrm{Kv}$, 管電流 $10 \mathrm{KA}$ 以上, 出力が $0.5 \mathrm{~m}$ で $5 \mu \mathrm{C} /$ kg で安定した出力が得られたという報告であった。

演題(1)〜(3)でのフラシュX線関係では, 每年目を見張るような報告 であり，今後の研究にますます期待するものである。

演題(4)では, ヘリカルスキャンについては, 従来 CTに比べスライ スが厚くなるため体積測定では，㕵差が問題になっています。従来 CTとヘリカルスキャンとの比較した結果，日常での条件での撮影で は，従来 CTでは，誤差のバラシツキが大きいとの報告でした，誤差の バラッキを小さくすることが可能であるなら補正值の利用等により 精度向上が図れる可能性もあり，有意義な報告であり，次回の報告に 期待したい.

演題(5)では，CT 検査特に胸部撮影では，2 種類の再構成画像を必 要とするが, 実空間フィル夕処理により再構成画像と同等な画像が得 られ，それにより保存画像が少ないこと，処理時間が短い，作業時間 の短縮など, 同じ問題を抱える施設には, 大きな意義のある報告であ った.

演題(6)では, 腹部血管造影特に肝臟の血管撮影を中心に画像に及ほ 卞因子について,ポジション, 呼吸, 造影剂の使用量, 検査時間, DSA との併用, 他㵴器との関係などについて検討したものです. 診断から 治療という応用範囲の広い分野ではあるが，体亲的に追求されてい た.さらに今後の報告に期待したい。

質問 (座長) 演題 1 へ 近年ポータブル装置もインバータ式と なってきているが, フラッシュ装置と比較した場合の利点, 欠点につ いておしえてください.

答（演者）瀑射数は数10回に限られますが,インバータ式よりも はるかに高周波で, しかもマイクロ秒域のX線照射時間で, ばらつき $1 \%$ 未满のX線強度が得られます。

質問（山形大 加賀） 演題 3 ヘ フラッシュX線管の焦点サイ ズを 3-8 $\mathrm{mm} \phi$ と述べましたが, 臨床上, ボケ等とが問題になるこ とはないか。

答 （演者）焦点サイズについて,タングステン棒を使用している ものについては, 原理として, タングステン棒の径を小さくすること によってサイズは小さくすることができる.臨床への応用としては, 今回の発表内での焦点では, 当然ボケの問題が生じる. したがって, 一般臨床用の装置とは比べることはできない。

質問 (坐長) 演題 5 フィルタにより CT 值は変わるのでし ょうか。

答 (演者) 当施設で使用している空間フィルタは, CT 值を変え て使用しているが,これは肺野の血管追跡や間質の描出に適した画像 を得るため, コントラストを少しねかせた空間フィルタを使用してい るためであります。もし CT 值を変えると不都合であれば, フィルタ 一マトリックの係数の和が 1 になるように設定すれば, システムの再 構成関数と同じ CT 值にすることも可能です。

画像技術（I）

\section{8. 上部消化管撮影における撮影条件の検討}

座長 嶋中祐次 (青森県立中央病院)

JR 仙台病院放射線科

○櫻井政史・高橋秀生・佐藤栄一郎・武田誠一・高橋勝夫 設楽光男・芳賀正一・鈴木精義

上部消化管撮影に扔りる撮影条件を,被写体厚の違いによるコント ラストの点から検討した。

硫酸バリウムの減弱係数と水ファントムによる直接線含有率を測 定した。部消化管二重造影における被写体を均一な吸収体と内壁に コーティングがされたバリウムと仮定し, 湘定結果よりバリウム部と それを含まない部のコントラストを計算した。計算結果より一定コン トラストを得る被写体厚一管電圧の関係を得た。

この関係は, グリッドの違いや内壁にコーティングされたバリウム
の濃度, 厚さにより異なるが, 被写体厚の違いによるコントラストの 変化は, 管電圧の調整による補償が可能である。

9. 非相称フィルム/スクリーンシステムの装置による特性の検討 総合水沢病院放射線科

○小島 実・佐藤一浩・佐藤 進・佐藤若夫・菊池 充 上野秀昭

〔目的〕 非相称感材の適正電圧を三相12パルスの使用で，BRH 法 に基づく評価と $\mathrm{Al}$ 濃度曲線より推定しその電圧を基にポータブル 写真との均質化も試みた。

〔結果〕インサイトシステムを使いボランティアの胸部とファン トムを視覚評価した所，コントラスト，解像力等の物理評価及び肺 野，縦隔，助骨等の評価は90〜 $100 \mathrm{kV}$ が良加った。 また，等条件で撮 影した $\mathrm{Al}$ 濃度曲線を利用したコンデンサ式ポータブルとの線質比 較においで6 mAs 以内では近似的に等しく，10：1リスホルムを組 み合わせることにより，病室撮影でも画質を近づける事ができた。

10. X線フィルムの感色性を考慮したネームプリンタの改造 石巻赤十字病院放射線科部

○石井出一・曽根哲市・西村章三・鴆田雅博・为川順一 仁杉好一・五十嵐和正・溥孝幸・木村成子・千葉美洋 齋藤春夫

昼光色ストロボライト光源を用いるネームプリンタ SEIKO-IDF

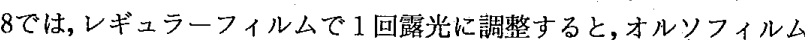
では $3 \sim 4$ 回露光が必要となる.これに対し, タングステンランプ光 源を用いるネームプリンタ SEIKO-3 型では, いずれも 1 回露光で十 分であった。これは光源の色の帯域の差によるものと,レギュラーと オルソフィルムとで感色帯域扔よび感度に差があり過ぎるためであ り,昼光色ストロボライトでは露光回数に差を付ける必要があるがカ ラーアクリル板などのフィルタを用いて光源の色帯域を狭めること で両フィルムの感度差が縮小し, 共に 1 回の露光で良好なネームプリ ントが出来るようになった.

11. 45秒現像処理導入に伴う全面オルソ移行時の撮影条件の検討 一低管電圧領域でのレギュラーシステムとの比較一 泉崎村立病院放射線部 $\bigcirc$ 辺見秀一

〔目的〕富士メディカル社製自動現像機 “CEPROS-M”が設置さ れたのを機会に, 45秒迅速現像処理を導入すべくオルソシステムへ全 面的に移行した.オルソ化の問題点として低管電圧領域での感度の低 下が挙げられるが,オルソシステムでの撮影条件を，これまで使用し てきたレギュラーシステムのものと比較検討した。

〔結論〕全面オルソ化に当たり,低管電圧領域での撮影条件を見直 す良い機会でもある。この領域で増感紙 (HR-3, HR-4) と管電圧 $(50,55,60 \mathrm{kV})$ の計 6 通りの組み合わせを考えてみたが，鮮鋭度を 重視するのか, コントラストを重視するのか, 被懪線量を考慮に入れ た上で理想的な撮影条件の指針になるような報告が望まれる。

\section{座長集約}

このセッション 5 題それぞれ内容が異なるものの共通していると ころはフィルムに関係しているところにあった、日常業務に直接関与 する問題点を色々検討をされ活用にこぎつけている.

今後, 被瀑線量低隇の観点加ら広くオルソ化が進むと思われるが管 電庄特性があることから種々の検討を加え有効な利用を心がけてい きたいものと思う。

管理技術（I）

\section{座長 市川敏夫（十和田市立中央病院） \\ 12. KYOKKO X線アナライザ modle 100用追加ソフトの試作 新潟県厚生連中央綜合病院放射線科}

○目黒正誠・水落佳宏・内田尚人・徳山克彦

$\mathrm{KYOKKO}$-X線アナライザを導入して約 1 年が過ぎた，使用して いると, 測定データの表示方法が少し物足りないので, 使用に応じた 表示に成るように追加ソフトを試作した. 表示の 1 つは測定管電圧の グラフ化である， 1 画面に 6 本までのグラフを描けるようにした, な おグラフのフルスケールは $150 \mathrm{kV}$ または $120 \mathrm{kV}$ を選べるようにし

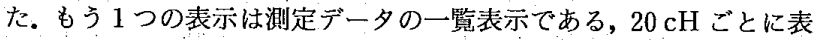
示し自由に前後表示出来るようにした. 测定データの印刷も一覧表形 式で印刷するようにした.これらの追加ソフトにより測定後のデータ 
管理, 表示等が良くなった. 今後とも使いやすい様に追加ソフトを試 作して行きたい。

13. X線アナライザによるコンデンサ式 X線装置測定に関する検討

東北大学医学部附属病院放射線部

○石屋博樹・佐藤和宏・千田浩一・佐藤弘之・斎 政博 营野典子・榊田秀晴・有馬宏寧

〔目的〕Non-invasive 型X線アナライザは，比較的簡便にX線装 置のQC が行えるため各施設で多用されている.X線アナライザの性 能評価については数多く報告されているが, 今回はコンデンサ式X線 発生装置に関して種々の測定を行い，此較検討した。

〔方法〕同一幾何学的条件でブリーダ (アルコ KV-201D), mdh1015c 型線量計を基準として，X線アナライザ（NERO6000B， MODEL100)による管電圧測定值, 撮影時間, X線量測定值を比較検 討した.

〔結果〕今回使用したX線アナライザは, コンデンサ式X線発生装 置の管電圧測定には適しているが, 撮影時間及び線量測定にはあまり 適していないと思われた。

14. 線量計 管理について

東北大学医学部附属病院放射線部

○浅野茂夫・針生俊一・管野義久・三津谷正俊

医療法人誠仁会鈴木二郎記念診療所 高橋勇守

東芝固定式コバルト-60遠隔治療装置は, 1980年より線量計校正専 用として使用している。線量計相互校正は，照射野の中心をレザービ 一ムで, 電離箱の高さ調整を 3 台のサイドポインターで, 同一照射野 SCD $150 \mathrm{~cm}, 50 \%$ 照射野 $50 \times 50 \mathrm{~cm}^{2}$ で先端付同校正で行う。線量計 のセッティングの誤差をさ $2 \mathrm{~mm}$ とするとセッティング時の電離箱 と線源間距離の变化による誤差は, $\pm 0.27 \%$ 以内である. 又, 照射野の $6 \mathrm{~cm}$ の範囲での線量分布の誤茥は, 約 $\pm 0.16 \%$ 以内で, セッティング による誤差の総計は $0.5 \%$ 以内の精度を持つ. 気圧計と温度計は, 検 定証書付である.気圧計はフォルタン型で 7 年間で補正值が +0.07 か $ら+0.14 \mathrm{mb}$ に, 又温度計も $5^{\circ} \mathrm{C}$ 毎に補正值が変動した。

\section{5. 衝撃波結石破砕装置使用状況（故障内容の分析）}

岩手医科大学付属病院中央放射線部

○松村 豊・目時 毅・及川 巧・鎌田雅義・村中健太 渡辺良政・村田 明・伊藤和弘・藤根賢 佐々木勝秋・秋津武志

〔目的〕故障による患者への影響 (治療の一時的中断, 中止, 延期) を少なくするための第一歩として, 故障や異常について分析し, 検討 したので報告する.

〔結果〕故障の $29 \%$ が致命故障， $22 \%$ が重故障であった.

患者への影響は，49\%が致命故障，33\%が重故障によるものであっ た.

致命故障と重故障の主なものとしては, 衝撃波発生ヘッドの破損に よるものが $23 \%$, 実際には故障でなかった故障と修理点検後に起こっ た故障を合わせて $23 \%$ あったた。

16. CT のスライス厚測定（フィルムと CR を利用して）

山形大学医学部附属病院放射線部

○丹 義雄・小松田泰・佐藤俊光・佐藤昌見・江口陽一 山田金市・木内繁夫

〔目的〕フィルムと CR 用いた線量プロフィールからCTのス ライス厚測定を試みた。

〔方法〕 (1) 治療計画用フィルムとイメージングプレートをそれ ぞれ回転中心部に水平に置き, 垂直方向より照射した. (2) (1)と同㥞 の状態で側方より照射した。(3) (1)と同様な状態で $360^{\circ}$ スキャンを行 なった.(4) (1) (3)のフィルムに対しマイクロデンシトメータの走査 を，I・Pに対しては CR のデー夕解析を行ない中心部の半值幅を求 めた。

〔結果〕1)フィルムでは公称厚 $10 ， 5 ， 1.5 \mathrm{~mm}$ に対し 10.2 , $5.2,2.3 \mathrm{~mm}$ であった. 2) CRでは公称厚に対し $10 \mathrm{~mm}$ $11.7 \sim 12.1 \mathrm{~mm}, 5 \mathrm{~mm}$ で6.9 7.1 mm, $1.5 \mathrm{~mm}$ では $3.7 \sim 3.9 \mathrm{~mm}$ であった. 3）公称厚 $1.5 \mathrm{~mm}$ では特に湘定值との差が大きかった。 座長集約

このセッションでは, X線アナライザに関するもの 2 題と, 線量 計, 衝撃波結不破砕装置, CT のスライスに関するもの各 1 題ずつ,
計 5 題の発表であった.

演題12はX線アナライザの管電圧データーを, パソコンに数表と, グラフで表示するソフトの陚作である.データーをプリントアウトし て日常のチェックに活用しているが, 既製のソフトではなく，自作ソ フトの製作に意欲が感じられた。

演題13はコンデンサー式発生装置を 2 種類のX線アナライザで測 定し, 基準測定器との数值を比較した結果, 管電圧に関しては良好な 相関が得られているが, 撮影時間, 線量測定については異差があり, これらは装置のQC には適していないというものであった. 演者らは これまでに, 発生方式の異なる装置での検討を数多く行なっており, これらのデータをもとに, 今後の発展を期待したい.

演題14は測定器の管理の在り方と, 測定方法について述べた。測定 器を高い精度で維持管理するには, 特性を十分把握した測定手法と管 理が必要であって, 精度維持の努力の跡が伺われる.さらなる精度向 上には標準センターによる比較校正も必要となるであろう。

演題15は破碎装置故障による患者への影響を少なくするために, 故 障内容を分析, 検討をした報告である. 装置の故障状況を知ることは 重要で，サービスマンが必要なもの, あるいは，自己で直せるもの， また，回復時間の予測などの判断ができ，これらの情報は直接患者サ ービスにつながるといえるからである.

質問 座長 衝揧発生ヘッドは消耗品とのことだが,どこが破損す るのか.

答 衝撃波発生板である.リソスターのヘッドは今までに 6 回交換 している.

質問 座長 1 回の shots 数の上限は.

答 身体への影響も考慮して上限を五千発にしている.

演題16は治療計画フィルムと CR の IP を用いて CT のスライス厚 を測定した. フィルムではマイクロデンシトメーターで, IPでは CR のデータ解析を行ない半值幅を求めた結果, 公称厚 $1.5 \mathrm{~mm}$ では共に 測定值との差が大きいと報告している.

質問 片倉(福島県立医大) なぜ, その様な方法で測定したのか.

答 1 . 当施設には専用ファントム無く, 使用機会も得がたいので 感度プロフィールからの测定ができない.

2. 測定対照 CT 装置は, 㭘出器直前に絞り機構が無いため線量プ ロフィールと感度プロフィールとの差は少ないと思われる。

3. ファントムを使用した CT 值プロフィールからの測定には次の ような問題点もある。

1）フィルタ関数やマトリックスの違いにより CT 值に差が出や すい.

2）薄いスライスでは測定誤差が出やすい.

以上の事より，今回我々は線量プロフィールの FWHM からスラ イス厚の測定を行なった。

\section{放射線治療技術・ RI 検查技術}

17. 輸血用血液製剤への照射法の検討

座長 工藤亮裕（弘前大学附属病院）

東北大学医学部附属病院

○佐久間俊光・針生俊一 - 菅野義久 - 三津谷正俊 - 浅野茂夫 医療法人誠仁会鈴木二郎記念診療所 高橋勇守

〔目的〕輸血による副作用に移植片対宿主病（P. T.GVHD）があ る。これの予防法として血液製剤に放射線照射を行う方法が広く採用 されている.今回, 生体肝移植に必要な多数の血液製剤に対し照射方 法を検討した.

〔結果扔よび考察〕 ${ }^{60} \mathrm{Co}-\gamma$ 線, $15 \mathrm{MeV}$ 電子線, $10 \mathrm{MV}-\mathrm{X}$ 線の照射 法を比較した。 その結果, $10 \mathrm{MV}-\mathrm{X}$ 線の対向 2 門照射で水槽に血液製 凨をつり下げて行う方法が, 数個の血液を一度に照射でき,また血液 製剤に均一な線量を与えることができるので最適な方法と考えられ る. 現在は心血管系の手術にも適応範囲が広がり, 当院では照射依頼 が増加し，血液照射にも限界がきている。

18. リング型 SPECT 装置 SET-050による rCBF の測定 $\left({ }^{133} \mathrm{Xe}\right.$ ガス 吸入法)

新潟大学医学部附属病院放射線部

O大滝広雄・野口栄吉・山崎芳裕・長沢 弘

新潟大学放射線医学教室 小田野行男 